\section{THE EFFECT OF TRANSFER DISTANCE TO LOWER BACK TWISTING AND BENDING PATTERNS IN MANUAL TRANSFER TASK}

Radin Zaid Radin Umara,b*, Muhammad Naqiuddin Khafiza, Nazreen Abdullasimc, Fatin Ayuni Mohd Azli Leea, Nadiah Ahmada,b

aFakulti Kejuruteraan Pembuatan, Universiti Teknikal Malaysia Melaka, Hang Tuah Jaya, 76100, Melaka, Malaysia

bCenter of Smart System and Innovative Design, Universiti Teknikal Malaysia Melaka, Hang Tuah Jaya, 76100, Melaka, Malaysia

cFakulti Teknologi Maklumat dan Komunikasi, Universiti Teknikal Malaysia Melaka, Hang Tuah Jaya, 76100, Melaka, Malaysia
Article history

Received

15 January 2020

Received in revised form

26 October 2020

Accepted

25 January 2021

Published online

23 February 2021

*Corresponding author radinzaid@utem.edu.my

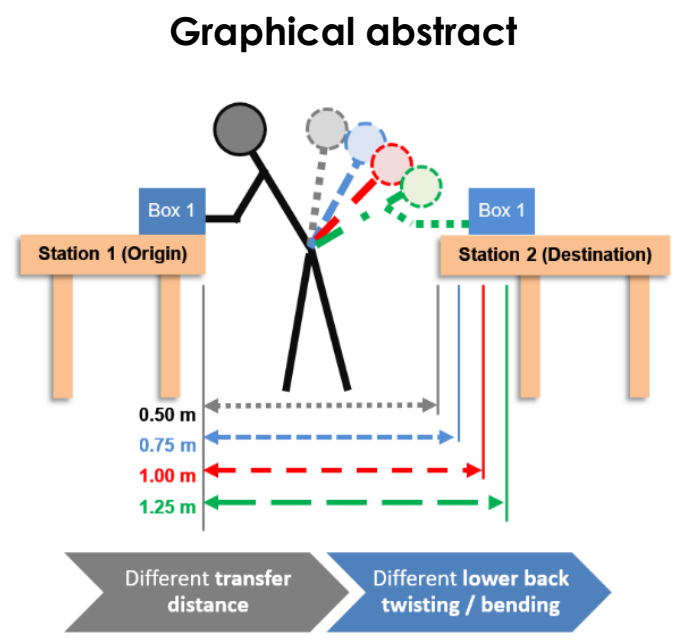

Graphical abstract distance twisting / bending

\begin{abstract}
Manual material handling (MMH) activities utilize human's effort with minimal aid from mechanical devices. MMH is typically associated with poor lower back posture which can lead to lower back injury. The likelihood to develop musculoskeletal disorders (MSDs) increases when poor working posture exist in combination with repetition and/or forceful exertion. In manual transfer activity, the distance between lifting origin and destination could affect workers' exposure on poor lower back working posture. An experimental study was conducted to investigate the effect of transfer distance to lower back twisting and bending pattern in manual transfer activity. Positional body joints data of 26 male subjects were captured using the combination of motion capture (MOCAP) system with MVN studio software. Calculated data were plotted against time to track subjects' lower back twisting and bending behavior. In general, longer transfer distance would result in smaller twisting angle but higher bending angle. Statistical analysis in this study suggests $0.75 \mathrm{~m}$ to $1.00 \mathrm{~m}$ as the optimum transfer distance to balance lower back twisting and bending exposure on workers. This study is envisioned to provide insights for practitioners to consider space requirements for MMH activity to minimize lower back twisting and bending, and consequently the development of MSDs.
\end{abstract}

Keywords: Transfer distance, lower back posture, ergonomics, manual material handling, palletizing task

\begin{abstract}
Abstrak
Pengendalian manual adalah aktiviti kerja yang menggunakan tenaga manusia sepenuhnya tanpa bantuan alatan mekanikal / bantuan yang minimum. Aktiviti pengendalian manual sangat sinonim dengan postur tulang belakang yang berisiko terhadap kecederaan. Risiko kecederaan di bahagian tulang belakang meningkat apabila postur yang tidak sihat digabungkan bersama daya yang berat dan/atau aktiviti yang berulang-ulang. Dalam aktiviti pengendalian manual, jarak pengendalian beban boleh mengurangkan pendedahan pekerja terhadap postur tulang belakang yang tidak sihat. Satu kajian telah
\end{abstract}


dijalankan untuk mengkaji kesan antara jarak kendalian beban keatas tingkah laku postur tulang belakang. Data bagi 26 subjek lelaki telah dianalisa menggunakan sistem analisa gerakan (MOCAP) bersama perisian MVN Studio. Secara keseluruhan, jarak kendalian beban yang jauh akan menyebabkan sudut pusingan tulang belakang yang rendah dan sudut bongkok tulang belakang yang tinggi. Analisa statistik menunjukkan bahawa jarak kendalian optimum adalah antara $0.75 \mathrm{~m}$ hingga $1.00 \mathrm{~m}$ bagi menyeimbangkan kesan keatas sudut pusingan dan sudut bongkok tulang belakang subjek. Kajian ini dijangka untuk memberikan kesedaran dan maklumat kepada pengamal industri untuk mempertimbangkan keperluan ruang untuk menjalankan aktiviti pengendalian manual seterusnya mengurangkan risiko kecederaan keatas pekerja.

Kata kunci: Jarak kendalian beban, postur tulang belakang, ergonomik, pengendalian manual, aktiviti kerja palet

(c) 2018 Penerbit UTM Press. All rights reserved

\subsection{INTRODUCTION}

Manual material handling ( $\mathrm{MMH}$ ) is used widely in various industries, especially in developing countries as a mean to transfer any physical material from one place to another. $M M H$, which relies heavily on human's physical effort through various activities such as lifting, pushing, and carrying is considered to be one of the most common causes of occupational fatigue and lower back injury [1, 2, 3]. From ergonomic perspective, there are multiple risk factors associated with $\mathrm{MMH}$ including poor working posture and forceful exertion [4, 5]. Strenuous handling activity that demands workers to adopt poor posture adds internal stress on muscles, tendons, ligaments, and joints, thus increasing the likelihood for the worker to develop Work-related Musculoskeletal Disorders (WMSDs) after prolonged exposure to $\mathrm{MMH}[6,7,8,9]$.

WMSDs are pain, injury, and damages on human's muscular system due to work demands [10]. WMSDs affect muscles, tendons, ligaments, joints, nerves, and other components in the muscular system, eventually limiting the motion of affected body parts. According to annual report from Social Security Organisation Malaysia (2014), a total of 675 accidents associated with WMSDs were recorded in 2014 as opposed to 238 and 14 in 2010 and 2006 respectively [11]. This indicates an increasing trend at an alarming rate. One of the main contributing factors of MSDs is heavy, manual material handling activity [12]. Trunk extension and twisting in $\mathrm{MMH}$ activities has been documented by researches as established risk factors to WMSDs [13, 6].

Workers exposure to lower back twisting, bending, and other poor body posture during MMH can be minimized through ergonomic interventions in their workplace. Through effective ergonomic interventions, musculoskeletal health related issues may be reduced, and work productivity may be improved $[14,15,16]$. In addition, proactive ergonomic application during front end engineering design stage has been demonstrated to generate the best outcomes in terms of work quality and productivity [17]. Ergonomic interventions consider multiple factors including work area layout, working space, lift heights, task frequency, and many more to maximized the compatibility between workers and work tasks [18, 19]. For example, an experimental study conducted by Mehta (2013) demonstrates that trunk extension and twisting degree can be controlled by separating the distance between lifting origin and destination [20]. In wider transfer distance, subjects are cognitively encouraged to step and turn their entire body thus reducing axial twisting and forward bending on the spine.

While increasing lifting origin and destination is shown to reduce lower back twisting and bending, the downside is that it uses more space and decrease material handling efficiency in term of task completion duration. In addition, ergonomics awareness and work habits can also affect twisting and bending behaviors. Joints motion and back loading when performing MMH task can differ from one individual to another [21]. Hence, this study aims to investigate the effect of different transfer distance requirements to lower back twisting and bending behavior during repetitive transfer task. The outcome of this study is envisioned to provide general insight on optimum distance range that can be utilized in front end workstation design process.

\subsection{METHODOLOGY}

\subsection{Overview}

Randomized repeated measure experiment was designed to investigate the effect of transfer distances to lower back twisting and bending behavior during manual handling activities. Independent variable set in this study was the transfer distances at 4 levels $(0.50$ $\mathrm{m}, 0.75 \mathrm{~m}, 1.00 \mathrm{~m}$, and $1.25 \mathrm{~m})$. Dependent variables 
were the corresponding subjects' lower back twisting and bending angles data. These data were collected through the use of body motion capture system XSENS (XSENS Technologies, Netherlands), which utilized multiple accelerometers located on different body joints to capture acceleration data on different body parts. Open source programming software, Processing, was used to convert acceleration data from XSENS into positional $x, y$, and $z$ coordinates. These coordinates were collected continuously throughout the manual handling activities at a sampling rate of $30 \mathrm{~Hz}$. Trigonometric equations were utilized to translate collected coordinates in space into lower back twisting and lateral bending behavior for each subject. Statistical and observational analyses were conducted to evaluate the differences in the effect of transfer distances to lower back twisting and bending patterns, across subjects.

\subsection{Subjects}

A total of 26 subjects ranging from $23-24$ years old (Mean $=23.88, S D=0.35$ ) were recruited in this study. All participants were screened to ensure that they do not have prior musculoskeletal history that could affect the way they perform the manual handling task including any injuries or existing pain that might restrict their normal range of motion.

\subsection{Data Collection}

Each subject was asked to fill the consent and demographic forms upon arrival, before being fitted into wearable XSENS suit. Each subject was instructed to transfer four boxes weighing $10.9 \mathrm{~kg}$ from station 1 to station 2, as per experimental setup shown in Figure 1. The set weight was based on another similar study conducted among American population [20]. Lift origin and destination are fixed at $0.83 \mathrm{~m}$ height from floor. This height represents elbow height of Malaysian population, at $5^{\text {th }}$ percentile [22]. The horizontal distance between the two stations are adjusted accordingly at $0.5 \mathrm{~m}, 0.75 \mathrm{~m}, 1.0 \mathrm{~m}$, and $1.25 \mathrm{~m}$. Experimental treatment orders were arranged using counterbalancing technique to minimize potential confounding bias.

Each subject was asked to complete few rounds of practice before data commencement begins. No specific instruction was given on handling technique, and each subject was instructed to perform handling at a self-determined normal pace. These practice rounds are crucial to ensure that subjects use consistent lifting strategy throughout the experiment, as well as to use specific transfer strategies they are most comfortable with. Positional data were then collected as each subject performed 4 repetitions of box transfer task from station 1 to station 2, for all 4 transfer distances, as shown in Figure 2.
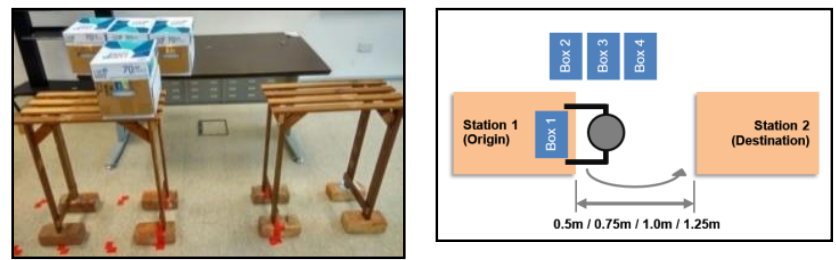

Figure 1 Workstation setup for manual material handling experiment (left). Top view of workstation layout. Subject's orientation indicates fixed initial position (right)
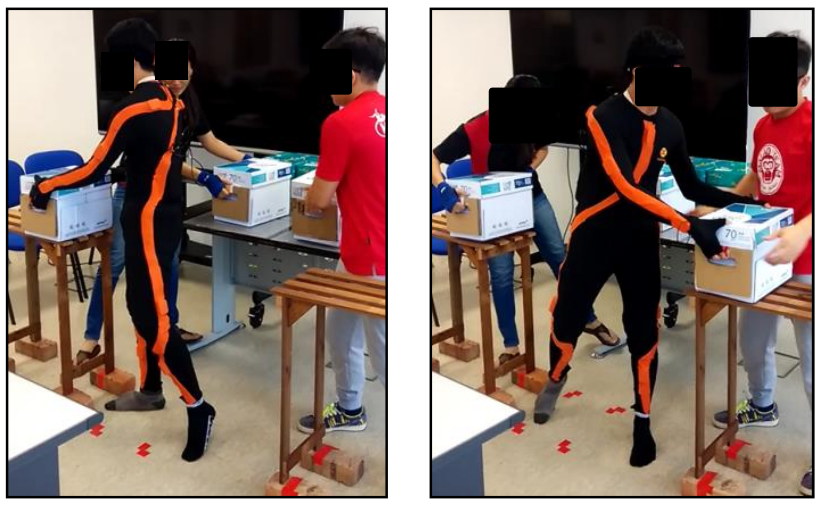

Figure 2 Subject performing load transfer task from Station 1 to Station 2

\subsection{Data Processing and Analysis}

\subsubsection{Processing Lower Back Twisting \& Bending Data}

Raw acceleration data of left hip, right hip, left shoulder, and right shoulder from each subject were obtained from XSENS system, before being processed through the Processing software, where an algorithm was developed to convert raw acceleration data into positional data. Trigonometric methods were used to determine low back bending and twisting angles, from the extracted positional data. The angle differences between two intersecting hip and shoulder lines was calculated and plotted (from 'top view') using Microsoft Excel with respect to time as 'lower back twist angle'. These plots show lower back twisting pattern on each subject throughout manual handling activity process. Some data point samples from calculation were verified using Cinema 4D software (MAXON Computer GmbH, Germany) which has a proprietary algorithm to view (but not extract) data angles directly from XSENS data. Similarly, positional data of hip and chest were extracted to track subject's lower back bending pattern. The angle between hip-chest line and horizontal $\mathrm{x}$-axis was calculated and plotted (from 'side view') with respect to time as 'lower back bending angle'. Data point samples from calculation were also verified using Cinema 4D software. Absolute twisting and bending magnitude were then calculated by extracting the 
maximum and minimum angles of twisting and bending.

\subsubsection{Data Analysis}

Descriptive statistics analyses were performed on absolute twisting and bending magnitude for each subject. Normality of data was checked prior to statistical analysis. Mauchly's test was conducted to prove sphericity assumption and repeated measures ANOVA with post-hoc Bonferoni correction were conducted to check if there are any significant differences on twisting and bending magnitude across different transfer distance. The analyses were conducted using JASP statistics packages (Wagenmakers, Amsterdam). In addition, observational analysis was conducted on lower back twisting and bending behavior to check for occurrence of repeated patterns such as symmetrical and asymmetrical lower back twisting.

\subsection{RESULTS AND DISCUSSION}

\subsection{Descriptive Statistics on Lower Back Twisting and Forward Bending behaviors}

In this study, lower back twisting is calculated as the angle between two intersecting lines: right to left shoulder line and right to left hip line, in which the lines are plotted from top view. On the other hand, lower back bending is calculated from the angle between shoulder-hip line and horizontal line, in which the lines are plotted from side view. Table 1 shows the mean and standard deviation of average twisting and bending angle across 26 subjects. Early analysis on the table suggests that as transfer distance increases, twisting angle decreases whereas bending angle increases.

Table 1 Mean and standard deviation of average twisting and bending angle $(n=26)$

\begin{tabular}{ccccc}
\hline $\begin{array}{c}\text { Transfer } \\
\text { Distance } \\
(\mathbf{m})\end{array}$ & \multicolumn{2}{c}{ Twisting Angle $\left(^{\circ}\right)$} & \multicolumn{2}{c}{ Bending Angle $\left(^{\circ}\right)$} \\
Mean & SD & Mean & SD \\
\hline 0.50 & 65.394 & 11.224 & 6.832 & 1.805 \\
0.75 & 64.656 & 12.000 & 9.326 & 3.489 \\
1.00 & 54.455 & 10.746 & 13.685 & 3.619 \\
1.25 & 55.274 & 9.233 & 18.091 & 3.387 \\
\hline
\end{tabular}

Twisting magnitude values represent the sum of maximum twist angle in both left and right direction for each subject. In general, the data indicates that twisting angle decreases as transfer distance increases. The descriptive data shows similarity of twisting magnitude between $0.50 \mathrm{~m}$ and $0.75 \mathrm{~m}$, as well as between $1.00 \mathrm{~m}$ at $1.25 \mathrm{~m}$. However, there is a noticeable difference of approximately $10^{\circ}$ twisting angle between $0.50 \mathrm{~m} / 0.75 \mathrm{~m}$ and $1.00 \mathrm{~m} / 1.25 \mathrm{~m}$ transfer distances.
Similarly, graphs were plotted from relevant positional data of all 26 subjects to track their lower back bending behavior. From side view, the average angle between upper body and horizontal line were calculated and plotted throughout manual handling activity as subject's bending angle against time. The absolute maximum bending magnitude for different transfer distances across all subjects showed consistent and distinctive behavior. In general, subjects adopted minimum bending angle at shortest transfer distance $(0.5 \mathrm{~m})$ and maximum bending angle at longest transfer distance $(1.25 \mathrm{~m})$. As transfer distance increases from $0.5 \mathrm{~m}$ to $1.25 \mathrm{~m}$, the reach distance between subjects and loads increases thus forcing them to adopt larger lower back bending angle during manual handling activity.

\subsection{Test of Significance}

Processed data were found to meet normality assumption. Mauchly's test conducted using JASP statistics package showed good sphericity assumption for both lower back twisting ( $p=0.603$ ) and lower back bending $(p=0.766)$. Repeated measures ANOVA to test the pairwise comparison show significant effect of different transfer distances on lower back twisting values at $\mathrm{p}<0.001$. The repeated measures ANOVA with post-hoc Bonferroni correction showed significant differences on all transfer distances except for $0.5 \mathrm{~m}$ vs $0.75 \mathrm{~m}$ and 1.0 $\mathrm{m}$ vs $1.25 \mathrm{~m}$. Results of significant test for lower back twisting are as tabulated in Table 2 below.

Table 2 Post-hoc analysis results for lower back twisting between different transfer distances

\begin{tabular}{cccccc}
\hline $\begin{array}{c}\text { Comparison of } \\
\text { transfer distances } \\
(\mathbf{m})\end{array}$ & $\begin{array}{c}\text { Mean } \\
\text { Difference }\end{array}$ & $\begin{array}{c}\text { Standard } \\
\text { Error }\end{array}$ & $\mathbf{t}$ & Pbonf \\
\hline 0.50 & 0.75 & 0.738 & 1.774 & 0.416 & 1.000 \\
& 1.00 & 10.939 & 2.043 & 5.353 & $<.001^{*}$ \\
& 1.25 & 10.120 & 1.809 & 5.596 & $<.001^{*}$ \\
0.75 & 1.00 & 10.200 & 2.068 & 4.932 & $<.001^{*}$ \\
& 1.25 & 9.382 & 1.904 & 4.928 & $<.001^{*}$ \\
1.00 & 1.25 & -0.818 & 1.156 & -0.708 & 1.000 \\
\hline
\end{tabular}

Similarly, repeated measures ANOVA showed significant effect of different transfer distances on lower back bending values at $p<0.001$. The repeated measures ANOVA with post-hoc Bonferroni correction showed significant differences on all transfer distances except for $0.5 \mathrm{~m}$ vs $0.75 \mathrm{~m}$. Test of significance results for lower back bending are as tabulated in Table 3 below. 
Table 3 Post-hoc analysis results for lower back bending between different transfer distances

\begin{tabular}{cccccc}
\hline \multicolumn{2}{c}{$\begin{array}{c}\text { Comparison of } \\
\text { transfer } \\
\text { distances }(\mathrm{m})\end{array}$} & $\begin{array}{c}\text { Mean } \\
\text { Difference }\end{array}$ & $\begin{array}{c}\text { Standard } \\
\text { Error }\end{array}$ & $\mathbf{t}$ & $\mathbf{P}_{\text {bonf }}$ \\
\hline 0.50 & 0.75 & -2.494 & 0.628 & -3.971 & 1.000 \\
& 1.00 & -6.853 & 0.629 & -10.894 & $<.001^{*}$ \\
& 1.25 & -11.259 & 0.616 & -18.279 & $<.001^{*}$ \\
0.75 & 1.00 & -4.359 & 0.549 & -7.939 & $<.001^{*}$ \\
& 1.25 & -8.766 & 0.751 & -11.669 & $<.001^{*}$ \\
1.00 & 1.25 & -4.407 & 0.559 & -7.883 & $<.001^{*}$ \\
\hline
\end{tabular}

Signifies significant statistical difference.

\subsection{Observational Analysis on Twisting \& Bending Behavior}

Overall, data shows that as transfer distance increases, twisting angle decreases. Subjects are likely to turn the whole body rather than adopting hip twisting motion in longer transfer distance. On a closer look, the observational analysis revealed that all subjects in this study can be categorized into one of three different groups of twisting styles according to their lower back twisting behavior. Subjects categorized as 'Group 1' (35\% of subject population). adopted a more symmetrical twisting behavior. The subjects in this group were observed to ground their lower limbs at the middle of the transfer distance with fluid hip twist angle when twisting.

On the other hand, group $2135 \%$ of subject population) were observed to adopt asymmetric twisting angle at shorter transfer distance and shifted to more symmetrical twist angle at longer transfer distances. Asymmetrical twisting angle suggests more fixated feet movement and lower hip twist angle as opposed to subjects in group 1. This observation can be verified through closer look on positional data. As demonstrated in Figure 3 (top), subject \#3 from Group 1 shows consistent symmetrical lower back twisting. Twisting angle graph shows decreasing magnitude as transfer distance increases. In contrast, subject \#9 from Group 2 adopted asymmetrical twisting magnitude (dominant on one twist direction) at shortest transfer distance $(0.5 \mathrm{~m})$ but shifted to more symmetrical twisting magnitude at longest transfer distance $(1.25 \mathrm{~m})$ as shown in Figure 3 (bottom).

Lastly, group 3 (30\% of subject population) was observed to show a twisting style that is a combination of subjects both from group 1 and 2. The data generally shows inconsistent trend in both twisting magnitude and twisting direction across different transfer distances as shown in Figure 4.

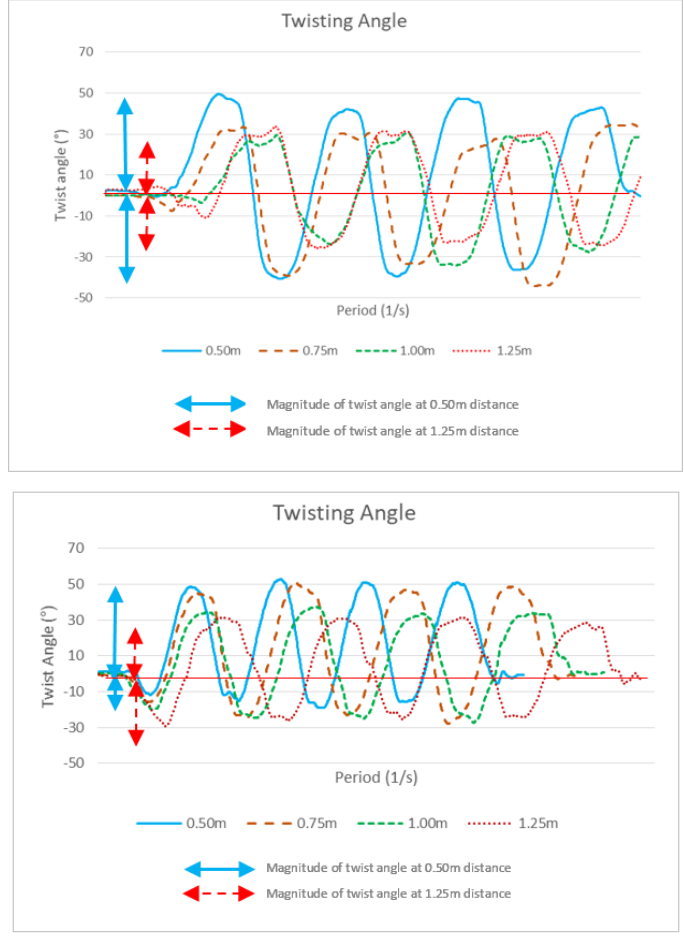

Figure 3 Twisting angle is symmetrical for subject \#3 representing subjects categorized as Group 1 (top). Shorter transfer distance generally results in greater twisting angle magnitude compared to longer transfer distance. In contrast, twisting angle is asymmetrical at shortest transfer distance and becoming more symmetrical at longer transfer distance for subject \#9, representing subjects categorized as Group 2 (bottom)

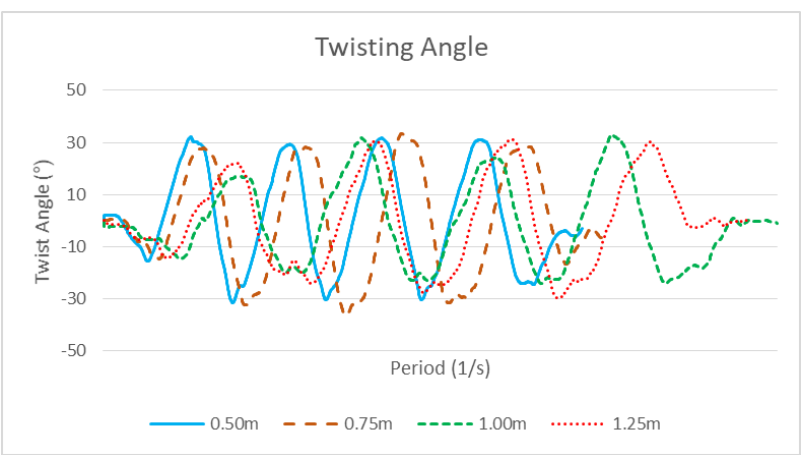

Figure 4 Twisting angle shows combination of symmetrical and asymmetrical trend across different transfer distance for subject \#5, representing subjects categorized as Group 3

Unlike lower back twisting where subjects adopted different twisting behavior, the trend of lower back bending behavior was generally observed to be consistent for all subjects. At short transfer distance, subjects adopted minimum forward bending angle. As transfer distance increases, subjects adopted forward bending at higher degree to reach and transfer load from lifting origin to lifting destination. Figure 5 below demonstrates increasing bending angle as transfer distance increases for subject \# 10. 


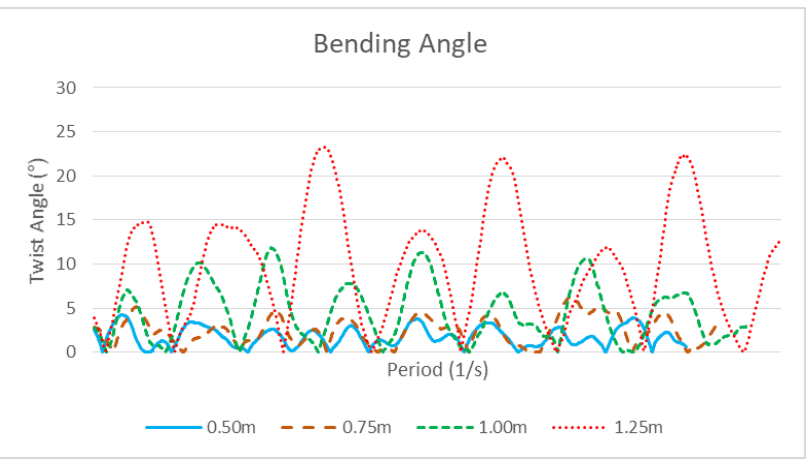

Figure 5 Bending angle for subject \# 10 shows increasing bending angle as transfer distance increases (typical to all subjects)

\subsection{Discussion}

The current study is one of the few studies that looked into the effect of transfer distance on lower back twisting and bending patterns in manual transfer task. Some subjects (categorized as group 1 in this study) were observed to adopt dynamic feet and hip movements, when space permits. Similarly, previous experimental study conducted by Plamondon et. al. (1995) on spine moment during asymmetrical lifting finds that human body would naturally adopt more flexible hip twist in order to compensate lower back twisting during manual transfer task [23]. However, different degree of hip twist compensation is observed in the current study. Subjects categorized in group 2 generally had more fixated feet and hip movement especially when space was limited. In longer transfer distances (where space permits), the subjects in group 2 adopted a more dynamic feet and hip movement similar to subjects categorized in group 1 .

In order for a subject to transfer a load located in front to a destination located behind, the subject naturally lifted one foot as he turned and planted it to a point where he could reach the final point comfortably. Up to this point, lower back twist was observed to be consistent at near $0^{\circ}$ as subject twisted their hip to compensate upper body rotation. As shown in Figure 6, this sequence is generally typical to all subjects during the initial transfer tasks cycle with some variance on hip twist angle. In this experiment, hip twist angle is defined as the subject's hip angle during lifting relative to hip's initial position. Once the first load was transferred, subject generally planted their feet and adopted lower back twisting back and forth to complete manual transfer task as demonstrated in Figure 7. Hip twist angle affected subject's maximum lower back twisting angle in both left and right direction. In this study, different hip twist values were observed across different transfer distances for all subjects thus affecting their lower back twisting behavior.

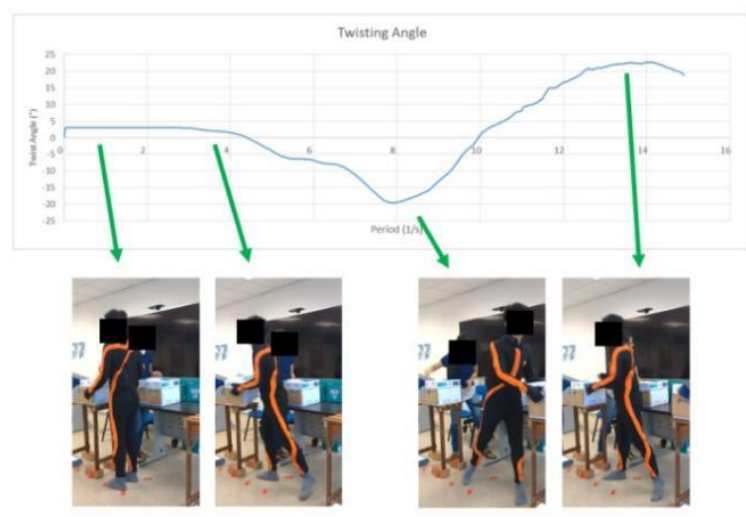

Figure 8-6 Typical lower back twisting sequence during initial transfer task (load \# 1 ) and their corresponding points on Twisting Angle graph. Notice that lower back twist angle remains constant as subject twist his hip and move his feet around

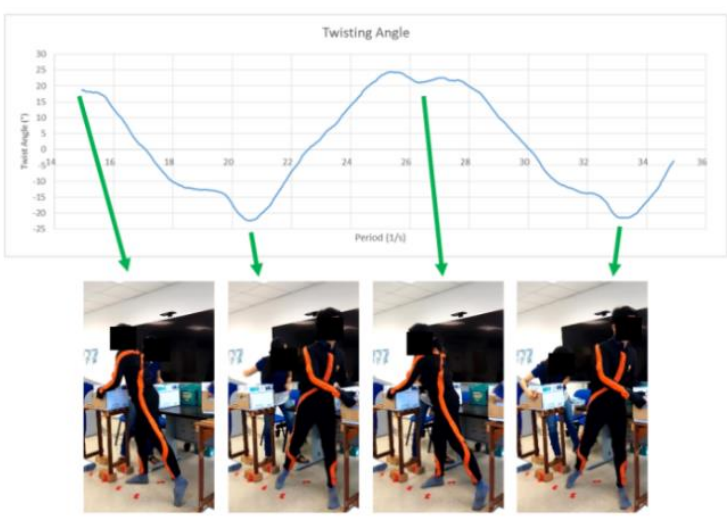

Figure 97 Typical lower back twisting sequence during subsequence transfer task (load \#2, \#3, and \#4) and their corresponding points on Twisting Angle graph

Dynamic hip twist results in more symmetrical lower back twisting magnitude whereas fixated hip twist results in asymmetrical lower back twisting magnitude. In a related study conducted by Granata and Marras (1995) on development of Electromyogram (EMG) assisted model for trunk loading, increasing asymmetric twist during lifting will result in increasing internal shear and compression force exerted by intervertebral discs in lower back region [24]. Over long task duration and numerous repetitions, the likelihood for intervertebral discs to acquire damages leading to lower back injury is higher in asymmetric lifting as compared to symmetric lifting $[25,26]$.

In similar experimental study conducted by Mehta (2013) on the effect of different transfer heights and distances on spine kinematics, separating the lift's origin and destination is demonstrated to encourage workers to stepped and turned their entire bodies thus reducing bending and twisting [20]. In this study, however, while it is true that subjects step and turn in large transfer distance, some still tended to plant their feet midway when repetition was needed. This pattern was generally true for subjects categorized in group 2 . 
At small transfer distance where space is limited, subjects stepped and turned however only up to a certain limit due to limited leg clearance. As shown in Figure 8, hip twist angle is observed to be less than $90^{\circ}$ from subjects' starting position. As a result, subjects' upper body adopted twist motion more dominantly in one direction to compensate their lower body limitation. As transfer distance increases and space permits, hip twist angle increases thus creating more balanced lower back twisting behavior in both left and right direction.
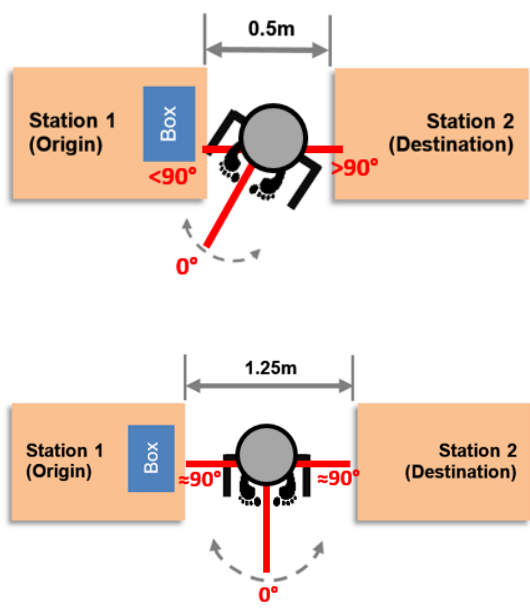

Figure 8 Different hip twist angles are observed at short transfer distance (top, $<90^{\circ}$ ) and long transfer distance (bottom, $\approx 90^{\circ}$ )

In repetitive manual handling activity, subjects typically place themselves at the midpoint between lifting origin and destination. As transfer distance increases, reaching distance increases thus forcing subjects to adopt poor bending posture at significantly higher degree to compensate longer reaching distance [26]. An industrial-based experiment conducted by Marras and Granata (1997) on EMG-assisted model to assess spine loading demonstrated that internal spine compression and shear loading increases as trunk extension motion and velocity increases [13]. Increasing internal spine loading shows that lower back bending posture during $\mathrm{MMH}$ task may increase the risk of lower back disorder.

Due the repetitive nature of the $\mathrm{MMH}$ task, subjects naturally tend to plant their feet at midpoint range between Station 1 (origin) and Station 2 (destination). By adopting more upper body twist and bend, the time taken to travel between origin and destination is minimized thus slightly decreasing task completion time [26]. This scenario comes at a risk when done repetitively without adequate recovery time. Repetitive lower back motion could speed up the wear and tear effect on subject's intervertebral disc leading to the development of WMSDs in the lumbar region $[27,28,29]$. Further study integrating single and cumulative exposure time with axial spine twisting and bending is envisioned to be beneficial in determining the risk of developing lower back injury during $\mathrm{MMH}$ task.

The difference between lifting strategies observed across subjects in this study is not necessarily a new finding. In a study on different lifting strategies during repetitive palletizing task, Plamondon et. al. (2014) found out that expert and novice workers adopted different lifting strategies during said task with the experts showing better lower back posture as opposed to the novices [21]. Another study conducted by Chen (2000) on lifting dynamics after localized arm fatigue concluded that lifting strategies may change over a task duration [30]. For instances, when arms become tired, our body would try to compensate the fatigue by adopting different lifting strategy. The results from his study shows that arm fatigue would result in an increase of lower back loading to thus increasing the risk of lower back injury. In the current study setup, subject was not bounded with fix lifting strategy such as foot placement, hip twist angle, and time restriction. In future study, controlling other variables that might affect the lower back twisting and bending behavior is expected to provide more detail on the effect of different transfer distance on internal loading exerted by the spine during $\mathrm{MMH}$ task.

Overall, findings in the current study suggest that different transfer distances affect lower back twisting and forward bending behaviors, which can provide design implications information for engineers and designers. Shorter transfer distances provide less clearance in workspace thus encourage dominant twisting behavior. As transfer distance increases, subjects seem to be in transition from primarily twisting to a combination of twisting and forward bending. As transfer distance increases further, subject would naturally try to minimize unnecessary movements thus they tend to plant their feet midway and adopt dominant forward bending to reach and transfer loads. As part of a bigger study, authors' other publication looks into greater details in the space mappings of hip and wrist during similar manual transfer task and found that as transfer distance increases, space requirement for hip and wrist movement also increases on certain levels. Hence, the optimum transfer distance was found to be between $0.75 \mathrm{~m}$ to $1.00 \mathrm{~m}$ in order to balance lower back twisting and bending behavior of workers.

\subsection{CONCLUSION}

This study provides lower back twisting and bending behavior during manual handling activity at different transfer distances. Overall twisting pattern across different subjects showed maximum twisting magnitude at shortest transfer distance $(0.5 \mathrm{~m})$ and reduced twisting magnitude at longest transfer distance $(1.25 \mathrm{~m})$. On the other hand, overall lower back bending magnitude was minimum at shortest 
transfer distance $(0.5 \mathrm{~m})$ and maximum at longest transfer distance $(1.25 \mathrm{~m})$. Based on the observation of twisting angle and bending angle trend, it was generally distinctive to suggest that increasing transfer distance results in decreasing twisting angle and increasing bending angle. Statistical analyses in this study suggest the optimum transfer distance to be between $0.75 \mathrm{~m}$ to $1.00 \mathrm{~m}$ to balance lower back twisting and bending behavior of workers. In front-end workstation design involving repetitive manual handling activities, it is important for engineers to select an optimum transfer distance that reduces and balances between low back twisting and bending, thus minimize workers' exposure on risk to lower back injury.

\section{Acknowledgement}

The authors would like to acknowledge Universiti Teknikal Malaysia Melaka (UTeM) for providing support in this study. The study is partially funded by research grant INDUSTRI (IRMG) / ERGOWORKS / 2019 / FKPCOSSID / 100037. The authors acknowledge Lee Poh Yan and Nur Izzati Azri for their contributions in this study.

\section{References}

[1] Snook, S. H., Campanelli, V., and Hart, J. W. 1978. A Study of Three Preventive Approaches to Low Back Injury. Journal of Orthopaedic Medicine. 20: 478-481. DOI: https://doi.org/10.1097/00043764-197807000-00009.

[2] Bigos, S. J., Spengler, D. M., Martin, N. A., Zech, J., Fischer, L., Nachemson, A., and Wamg, M. H. 1986. Back Injury in Industry: A Retrospective Study in Injury Factors. Spine. 11: 246-251.

DOI: https://doi.org/10.1097/00007632-198604000-0001 1.

[3] Canadian Center of Occupational Health and Safety (CCOHS). 2016.2 Retrieved from: https://www.ccohs.ca/oshanswers/ergonomics/mmh/mm hintro.html.

[4] Shamsuddin, K. A., Ani, M. N. C., Ab-Kadir, A. R., and Osman, M. H. 2014. Analysis on the Work-Related Musculoskeletal Disorders (WMSD's) Based on Ergonomic Study in Case of Industry Study. International Journal Engineering Research. 3(4): 190-195.

[5] Yahya, N. M. and Zahid, M. N. O. 2018. Work-related Musculoskeletal Disorders (WMDs) Risk Assessment at Core Assembly Production of Electronic Components Manufacturing Company. IOP Conference Series: Materials Science and Engineering. 319: 1-7. DOl: https://doi.org/10.1088/1757-899X/319/1/012036.

[6] Zein, R. M., Halim, I., Azia, N. A. Saptari, A., and Kamat, S. R. 2015. A Survey on Working Postures Among Malaysian Industrial Workers. $2^{\text {nd }}$ International Materials, Industrial, and Manufacturing Engineering Conference, MIMEC2015. 2: 450-459. DOI: https://doi.org/10.1016/j.promfg.2015.07.078.

[7] Jaffar, N. A. and Abdol Rahman, M. N. 2017. Review on Risk Factors Related to Lower Back Disorders at Workplace. IOP Conference Series: Mater in Science Engineering. 226: 1235.

DOI: https://doi.org/10.1088/1757-899X/226/1/012035.

[8] Rahman, M. N. A., Zakaria, N. H., Masood, I., Adzila, S., and Nasir, N. F. 2016. Risk Assessment for Assessing the Subjective
Occupant Seating Discomfort Related Office Works. Information. 19(7B): 3025-3030.

[9] Jaffar, N., Abdul-Tharim, A., and Mohd-Kamar. 2011. A Literature Review of Ergonomics Risk Factors in Construction Industry. Procedia Engineering. 20: 89-97.

DOl: https://doi.org/10.1016/j.proeng.2011.11.142.

[10] Wang, D., Dai, F., and Ning, X. 2015. Risk Assessment of Work-related Musculoskeletal Disorders in Construction: State-of-the-Art Review. Journal of Construction Engineering and Management. 141(6): 1-15.

DOI: https://doi.org/10.1061/(ASCE)CO.1943-7862.0000979.

[11] Social Security Organisation. 2014. Annual Report. Retrieved March 15, 2018, from https://www.perkeso.gov.my/images/laporan_tahunan/L aporan_Tahunan_2014.pdf.

[12] Halim, I., Abdullah, R., and Ismail, A. R. 2012. A Survey on Work-related Musculoskeletal Disorder (WMSDs) among Construction Workers. Journal of Occupational Safety and Health. 9:1-6.

[13] Marras, W. S. and Granata, K. P. 1997. The Development of an EMG-assisted Model to Assess Spine Loading During Whole-body Free-Dynamic Lifting. Journal of Electromyography and Kinesiology. 7(4): 259-268. DOI: https://doi.org/10.1016/S1050-641 1 (97)00006-0.

[14] Radin Umar, R. Z., Ahmad, N., Halim, I., Lee, P. Y., and Hamid, M. 2019. Design and Development of an Ergonomic Trolley-Lifter for Sheet Metal Handling Task: A Preliminary Study. Safety And Health At Work. 10(3): 327-335. DOI: https://doi.org/10.1016/j.shaw.2019.06.006.

[15] Suryoputro, M. R., Wildani, K., and Sari, A. D. 2018. Analysis of Manual Handling Activity to Increase Work Productivity (Case study: Manufacturing company). MATEC Web of Conferences. 154: 1-5.

DOI: https://doi.org/10.1051/matecconf/201815401085

[16] Dul, J. and Neumann, W. P. 2009. Ergonomic Contributions to Company Strategies. Applied Ergonomics. 40(4): 745752.

DOI: https://doi.org/10.1016/j.apergo.2008.07.001.

[17] Kjaer-Hansen, J. 1999. Human Factors Module: A Business Case for Human Factor Investment (Industry report HUM.ET1.ST13.4000-REP-02). Retrieved August 20, 2018, from European Organisation for the Safety of Air Navigation.

[18] Haslegrave, C. M. 2007. What Do We Mean by a 'Working Posture'? Ergonomics. 37: 781-799. DOI : https://doi.org/10.1080/00140139408963688.

[19] Ozkaya, K., Polat, O., and Kalinkara, V. 2018. Physical Workload Assessmemt of Furniture Industry Workers by Using OWAS Method. The Ergonomics Open Journal. 11: 11-19. DOI: https://doi.org/10.2174/1875934301811010011.

[20] Mehta, J. P., Kim, T. H., Weiler, M. R., and Lavender, S. A. 2013. Effects of Transfer Distance on Spine Kinematics for De-Palletizing Tasks. Journal of Occupational and Environmental Hygiene. 11 (1): 1-8. DOI: https://doi.org/10.1080/15459624.2013.839878.

[21] Plamondon, A., Delisle, A., Bellefeuille, S., Denis, D., Gagnon, D., Larivière, C., and IRSST MMH Research Group. 2014. Lifting Strategies of Expert and Novice Workers During a Repetitive Palletizing Task. Applied Ergonomics. 45: 471481. DOI: https://doi.org/10.1016/j.apergo.2013.06.008.

[22] Karmegam, K., Sapuan, S. M., Ismail, M. Y., Shamsul Bahri, M. T., Shuib, S., Mohana, G. K., Seetha, P., TamilMoli, P., Hanapi, J. 2011. Anthropometric Study Among Adults of Different Ethnicity in Malaysia. International Journal of the Physical Sciences. 6(4): 777-788. DOI: https://doi.org/10.5897/IJPS10.310.

[23] Plamondon, A., Gagnon, M., and Gravel, D. 1995. Moments at the L5/S1 Joint During Asymmetrical Lifting: Effects of Different Load Trajectories and Initial Load Positions. Clinical Biomechanics. 10: 128-136. DOI: https://doi.org/10.1016/0268-0033(95)93702-U.

[24] Granata, K. P. and Marras, W. S. 1995. An EMG-assisted Model of Trunk Loading During Free-dynamic Lifting. Journal of Biomechanics. 28: 1309-1317. 
DOI: https://doi.org/10.1016/0021-9290(95)00003-Z.

[25] Kingma, I., Van Dieen, J. H., Looze, M. D., Toussaint, H. M., Dolan, P., and Baten, C. T. M. 1998. Asymmetric Low Back Loading in Asymmetric Lifting Movements Is Not Prevented by Pelvic Twist. Journal of Biomechanics. 31: 527-534. DOI: https://doi.org/10.1016/S0021-9290(98)00045-1.

[26] Lavender, S. A. and Johnson, M. 2009. Is There a Transfer Distance that Minimizes Twisting and Bending Motions of the Spine? Proceedings of the Human Factors and Ergonomics Society Annual Meeting. 53: 882-882.

DOI: https://doi.org/10.1177/154193120905301404.

[27] Driver, C. B. 2018. "Spondylosis" in e-medicinehealth. Retrieved from: https://www.emedicinehealth.com/spondylosis/article_e m.htm\#spondylosis_facts.
[28] Lop, N. S. B., Salleh, N. M., Zain, F. M. Y., \& Saidin, M. T. 2019. Ergonomic Risk Factors (ERF) and their Association with Musculoskeletal Disorders (MSDs) among Malaysian Construction Trade Workers: Concreters. International Journal of Academic Research in Business and Social Sciences. 9(9): 1269-1282.

DOI: http://dx.doi.org/10.6007/IJARBSS/v9-i9/6420.

[29] Yahya, N. M. and Zahid, M. N. O. 2018. Work-related Musculoskeletal Disorders (WMDs) Risk Assessment at Core Assembly Production of Electronic Components Manufacturing Company. IOP Conference Series: Material Science Engineering. 319: 012-036.

DOI: https://doi.org/10.1088/1757-899X/319/1/012036.

[30] Chen, Y. L. 2000. Changes in Lifting Dynamics after Localized Arm Fatigue. Industrial Ergonomics. 25: 611-619. DOI: https://doi.org/10.1016/S0169-8141 (99)00048-7. 